\title{
Health risk assessment of textile effluent reuses as irrigation water in leafy vegetable Basella alba
}

\author{
Mashura Shammi ${ }^{1,2} \cdot$ Mohammad Abul Kashem ${ }^{2,3}$ • Md. Mostafizur Rahman ${ }^{2,5}$ • \\ Md. Delwar Hossain ${ }^{2,4} \cdot$ Rashadur Rahman $^{2} \cdot$ M. Khabir Uddin ${ }^{2}$
}

Received: 9 April 2015/Accepted: 28 March 2016/Published online: 26 April 2016

(c) The Author(s) 2016. This article is published with open access at Springerlink.com

\begin{abstract}
Purpose The aim of this research was to assess the health risk of textile wastewater reuse as irrigation water on leafy vegetable (Basella alba) by comparing variable growth rate in different ration of wastewater and freshwater irrigation and assess their soil-to-plant transfer factor (TF) and health risk index (HRI).

Methods Pot experiments were laid out with five treatments including control with three replications with different irrigation schemes with textile wastewater collected from the untreated point source. The irrigation scheme was, $100 \%$ groundwater as control with four treatments as $75 \%$ groundwater: $25 \%$ wastewater, $50 \%$ groundwater: $50 \%$ wastewater, $25 \%$ groundwater: $75 \%$ wastewater and $100 \%$ wastewater.

Results Soil-to-plant TF in different treatments including control were in the order of $\mathrm{Pb}(1.0-1.7)>\mathrm{Cu}$ $(1.3-1.5)>\mathrm{Cd}(0.8-1.0)>\mathrm{Zn}(0.1-1.1)$. TF values of $\mathrm{Pb}$ and $\mathrm{Cu}$ in the range from 1 to 1.7 indicating their
\end{abstract}

Mashura Shammi

mashura926@gmail.com

1 Department of Environmental Pollution and Process Control, Xinjiang Institute of Ecology and Geography, Chinese Academy of Sciences, Urumqi 830011, Xinjiang, People's Republic of China

2 Department of Environmental Sciences, Jahangirnagar University, Dhaka 1349, Bangladesh

3 Youngone Group, Dhaka Export Processing Zone (DEPZ), Ganakbari, Savar, Dhaka 1349, Bangladesh

4 Soil Research Development Institute (SRDI), Dhaka 1207, Bangladesh

5 Faculty of Environmental Earth Science, Graduate School of Environmental Science, Hokkaido University, Sapporo, Japan accumulation in $B$. alba plants and their potential health risk by dietary exposure. The HRI for individual metal as well as cumulative HRI of the metals was less than unity (0.33) which indicated the consumption of the vegetables was considered to be safe for one harvest.

Conclusion Over many seasons of irrigation with wastewater, level of salinity and heavy metals can accumulate on the agriculture land and their long term consumption may link to a chronic health risk. Hence, consumption of these vegetables on regular basis should be avoided.

Keywords Textile wastewater reuses - Irrigation Transfer factor (TF) $\cdot$ Health risk index (HRI) - Basella alba

\section{Introduction}

Water, the vital material in all aspects of life on earth, plays an extremely important role for human being, socio-economic development and the existence of ecosystems (An et al. 2014). The quality and quantity of any water supply planning is highly important, especially when considering for irrigation purposes. However, the productive use of wastewater has also increased, as millions of small-scale farmers in urban and peri-urban areas of developing countries have no alternative sources of irrigation water (Qadir et al. 2010).

Textile and dyeing factories in the world pose major environmental threats because of large amount of water and dyes involved in manufacturing process (Ranganathan et al. 2007; El-Rahim et al. 2008). Textile wastewater contains substantial pollution loads in terms of $\mathrm{pH}$, temperature, color, chemical oxygen demand (COD), biochemical oxygen demand (BOD), total suspended solid (TSS), total dissolved solids (TDS), electrical conductivity 
(EC) and heavy metals. The value of these parameters has been reported to be very high in many literature compared to the values in Bangladesh Environment Conservation Rules (BECR' 1997) (MOEF/DOE/GOB 1997) standards set by the government of Bangladesh (Shammi et al. 2014; Khan et al. 2011; Ahmed et al. 2007; Mahfuz et al. 2004; Kabir et al. 2002). Two of the main concerns for wastewater reuse in agricultural irrigation are environmental and human security (Ganoulis 2012). The main positive effects of using wastewater are improved soil fertility, and as a result improved crop production through increased organic matter (OM) and macro- and micro-nutrient content (Pereira et al. 2011a), and environmental benefits such as reduced groundwater uptake and reduced direct discharge of residual waters (Muyen et al. 2011; Toze 2006).

However, soil pollution with heavy metals due to discharge of untreated urban and industrial wastewater is a major threat to ecological integrity and human well-being (Mahmood and Malik 2014). A high sodium adsorption ratio (SAR) of the wastewater implies a hazard of sodium (Alkali) replacing $\mathrm{Ca}^{2+}$ and $\mathrm{Mg}^{2+}$ in the soil through a cation exchange process that damages soil structure mainly permeability, and which ultimately affects the fertility status of the soil and reduce crop yield (Gupta 2005), and buildup of salinity in the soil (Klay et al. 2010). While wastewater irrigation builds exchangeable $\mathrm{Na}^{+}$up, the excessive $\mathrm{Na}^{+}$was leached out of the soil profile after a rainy summer season ( $>400 \mathrm{~mm}$ ) (Pereira et al. 2011b). Long term irrigation of farm lands with wastewater leads to contamination of soil and plant system with heavy metals (Salakinkop and Hunshal 2014). The soil and plant samples show higher values due to accumulation (Gupta et al. 2010). Bioaccumulation factors of heavy metals were significantly higher for leafy than for non-leafy vegetable (Zhuang et al. 2009). Dietary exposure to heavy metals, namely cadmium $(\mathrm{Cd})$, lead $(\mathrm{Pb})$, zinc $(\mathrm{Zn})$ and copper $(\mathrm{Cu})$, has been identified as a risk to human health through the consumption of leafy vegetable grown on contaminated sites with wastewater irrigation (Zhuang et al. 2009; Hu et al. 2013; Hu and Ding 2009; Nabulo et al. 2010; Intawongse and Dean 2006).
Millions of small-scale farmers in urban and peri-urban areas of developing countries like Bangladesh have no alternative sources of irrigation water for agriculture other than reuse of wastewater discharged from textile and dyeing factories. The textile wastewaters in Savar, Dhaka (Bangladesh) have been in use for irrigation since last many years. Although reuse of wastewater could be a potential method for reducing irrigation cost, improving crop production and reducing ecological damage by direct discharge, polluting soil directly while ground water and food crops indirectly. Soil pollution with heavy metals can be a major threat to ecological integrity and human wellbeing. However, very few reports have been found in Bangladesh related to the dietary exposure of heavy metals by consuming leafy vegetables (Jolly et al. 2013; Alam et al. 2003; Al-Rmalli et al. 2012). Therefore, the aim of this research is to assess the health risk of textile wastewater reuse as irrigation water on leafy vegetable (Basella alba) production by comparing variable growth rate in different ration of wastewater and fresh water irrigation and to assess their health risk from consumption.

\section{Methods}

\section{Species selection}

Malabar spinach (B. alba) is a fast-growing, soft-stemmed vine is a very popular vegetable in Bangladesh (Table 1) which was selected for the experiment.

\section{Experimental design}

The pot experiment was laid out with five treatments including control with three replications (Table 2). During the investigation, morphological parameters (average length of stems, leaf area and wet weight) of plants were noted in with the help of measuring scale and digital balance for two times, i.e., 7 and 40 days of emergence. Two randomly selected plants were used from each treatment pot for collecting physiological data. A germination test
Table 1 Scientific classification

\begin{tabular}{ll}
\hline Division: & Magnoliophyta \\
Class: & Magnoliopsida \\
Order: & Caryophyllales \\
Family: & Basellaceae \\
Genus: & Basella \\
Species: & B. alba
\end{tabular}

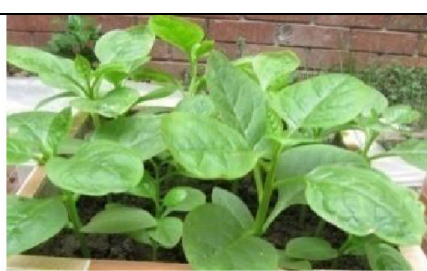

Basella alba 
Table 2 Irrigation scheme using textile wastewater

\begin{tabular}{llllrl}
\hline & Control & $\mathrm{T} 1$ & $\mathrm{~T} 2$ & $\mathrm{~T} 3$ & $\mathrm{~T} 4$ \\
\hline $\begin{array}{c}\text { Irrigation } \\
\text { scheme }\end{array}$ & $\begin{array}{c}100 \% \\
\text { groundwater }\end{array}$ & $\begin{array}{c}75 \% \text { groundwater: } 25 \% \\
\text { wastewater }\end{array}$ & $\begin{array}{c}50 \% \text { groundwater: } 50 \% \\
\text { wastewater }\end{array}$ & $\begin{array}{c}25 \% \text { groundwater: } 75 \% \\
\text { wastewater }\end{array}$ & $\begin{array}{c}100 \% \\
\text { wastewater }\end{array}$ \\
\hline
\end{tabular}

Table 3 Test report of physic-chemical properties of wastewater sample analysis

\begin{tabular}{|c|c|c|c|c|}
\hline Water quality parameters & Sample 1 & Sample 2 & Ground water & Irrigated land $^{\mathrm{a}}$ \\
\hline Chemical oxygen demand (COD) (mg/L) & 832 & 1023 & - & 400 \\
\hline Biochemical oxygen demand $\left(\mathrm{BOD}_{5}\right)(\mathrm{mg} / \mathrm{L})$ & 380 & 470 & $4.50-4.62$ & 100 \\
\hline Dissolved oxygen (DO) (mg/L) & 0.08 & 0.07 & $4.00-4.15$ & $4.5-8$ \\
\hline Total suspended solid (TSS) (mg/L) & 42 & 142 & - & 200 \\
\hline Total dissolved solid (TDS) (mg/L) & 4144 & 4231 & - & 2100 \\
\hline $\mathrm{pH}$ & 8.15 & 8.35 & $7.00-7.30$ & $6.5-8.5$ \\
\hline $\mathrm{EC}(\mu \mathrm{S} / \mathrm{cm})$ & 7390 & 7853 & $140-170$ & 1200 \\
\hline Total alkalinity (mg/L) & 795 & 750 & - & - \\
\hline Total hardness (mg/L) & 175 & 190 & - & - \\
\hline $\mathrm{Na}(\mathrm{mg} / \mathrm{L})$ & 4026.89 & 4066.69 & - & 200 \\
\hline $\mathrm{Ca}(\mathrm{mg} / \mathrm{L})$ & $8.63 \pm 0.05$ & $9.54 \pm 0.05$ & - & 75 \\
\hline $\mathrm{Mg}(\mathrm{mg} / \mathrm{L})$ & $3.83 \pm 0.02$ & $3.72 \pm 0.02$ & - & $30-35$ \\
\hline $\mathrm{Zn}(\mathrm{mg} / \mathrm{L})$ & $0.13 \pm 0.00$ & $0.14 \pm 0.00$ & - & 10.0 \\
\hline $\mathrm{Cu}(\mathrm{mg} / \mathrm{L})$ & $0.0096 \pm 0.00$ & $0.0036 \pm 0.00$ & - & 3.0 \\
\hline $\mathrm{Pb}(\mathrm{mg} / \mathrm{L})$ & $<0.0913$ & $<0.0913$ & - & 0.1 \\
\hline $\mathrm{Cd}(\mathrm{mg} / \mathrm{L})$ & $<0.25$ & $<0.25$ & - & 0.5 \\
\hline SAR & 12.76 & 13.14 & - & - \\
\hline
\end{tabular}

${ }^{a}$ Industrial wastewater quality standard Bangladesh Environment Conservation Rules (MOEF/DOE/GOB 1997)

was done prior to the experiment which indicated $100 \%$ germination in both $100 \%$ wastewater and $100 \%$ fresh water. Four seeds were planted in each pot. The pots were irrigated with groundwater as the source of freshwater, textile wastewater as well as the mixture of the two in different ratios (Table 2). The characteristics of groundwater are given in Table 3 .

\section{Collection and characterization of wastewater}

Wastewater used in this experiment was raw and untreated point source collected from a textile industry of Savar, Dhaka (Bangladesh) and transported by standard methods as mentioned in APHA (1998). The wastewater sample was a mixture of different procedures such as washing, dying and rinsing, etc. To get the general idea of the characteristics, wastewaters from two different times were collected as sample 1 in the morning and sample 2 in the afternoon and their mixture was used for the experiment purposes. Within collection of half an hour Physic-chemical parameters electrical conductivity (EC), $\mathrm{pH}, \mathrm{DO}$ was measured on the spot. EC, pH, and DO were measured by EC meter (EC 241, HANNA, Portugal), pH meter (Lab 851,
SCHOTT Instruments, Germany), and DO meter (H19143, HANNA), respectively. Total hardness was measured by complexometric titration using EDTA; alkalinity was measured by titration method, total suspended solids (TSS) by gravimetric method, chemical oxygen demand (COD) by the closed reflux titrimetric method and biological oxygen demand $\left(\mathrm{BOD}_{5}\right)$ by standard method (APHA 1998).

The sodium adsorption ratio (SAR) was calculated by the equation given by Richards (1954) in (meq/L) ${ }^{0.5}$.

$\mathrm{SAR}=\frac{\mathrm{Na}^{+}}{\sqrt{\frac{\mathrm{Ca}^{2+}+\mathrm{Mg}^{2+}}{2}}}$

where, $\mathrm{Na}^{+}, \mathrm{Ca}^{2+}, \mathrm{Mg}^{2+}$ are sodium, calcium and magnesium ion concentrations in meqL $\mathrm{L}^{-1}$.

\section{Collection and characterization of soil sample}

Soil was collected from the agricultural land near Savar and considered as background soil. The soil belongs to the Madhupur clay formation. The soils are brown and red mottled, strongly acidic, friable clay loam to clay soils over 
deeply weathered red mottled Madhupur clay. The top soil is $10-15 \mathrm{~cm}$ thick (Huq et al. 2013). The clay minerals present in the Madhupur Clay soil of different areas of Savar and Dhaka are kaolinite $(52.39 \%)$, illite (36.39\%) and small amount of illite-smectite $(11.21 \%)$ (Haque et al. 2013). Cation exchange capacity (CEC) of Madhupur clay is low, $\mathrm{pH} 6.9$ with poor moisture retention capacity (Hoque 1984).

Background soil before irrigation and that have passed 45 days after irrigation were collected, air-dried, ground by agate mortar and pestle, and sieved through a $150 \mu \mathrm{m}$ mesh size sieve for metal analyses. For the ease of data interpretation percent change of physic-chemical parameter after 45 days of irrigation was compared using the following formula

$\%$ Change $=\frac{\mathrm{N}_{\text {Sample }}-\mathrm{N}_{\text {background }}}{\mathrm{N}_{\text {background }}} \times 100$

$\mathrm{N}_{\text {background }}=$ background data obtained for different parameters.

$\mathrm{N}_{\text {sample }}=$ sample data obtained after different treatments with unit expressed in \%.

\section{Collection and characterization of vegetable samples}

Two randomly selected plants from five treatments with three replication pots were collected after 45 days of maturation. The plants were washed with double distilled water, chopped into smaller pieces, oven dried at $70{ }^{\circ} \mathrm{C}$ for 48-72 $\mathrm{h}$, weighed and placed in a dehydrator. The dried samples were then ground and passed through $150 \mu \mathrm{m}$ sieve.

One gram of dry matter was weighed into $50-\mathrm{mL}$ glass beakers, followed by the addition of $10 \mathrm{~mL}$ mixture of analytical grade acids of $\mathrm{HNO}_{3}$ (concentration $70 \%$ ) and $\mathrm{HClO}_{4}$ (concentration $70 \%$ ) in the ratio 5:1. The digestion was performed at a water bath (temperature $80^{\circ} \mathrm{C}$ ) to heat for $72 \mathrm{~h}$ until a light color solution was obtained. After cooling, the solution was made up to a final volume of $25 \mathrm{~mL}$ with distilled water in a volumetric flask. Triplicate digestion of each sample was carried out together. For soil sample analysis the same procedure was followed. Analysis of heavy metals in water, soil and plant $(\mathrm{Cu}, \mathrm{Pb}$ and $\mathrm{Zn})$ were carried out by FLAAS (Flame Atomic Absorption Spectrophotometer Model: SHIMADZU AA-6800 series) with the detection limit for $\mathrm{Fe}(0.5 \mathrm{mg} / \mathrm{L}) \mathrm{Cu}(0.0025 \mathrm{mg} /$ $\mathrm{L}), \mathrm{Zn}(0.01 \mathrm{mg} / \mathrm{L}), \mathrm{Pb}(0.09 \mathrm{mg} / \mathrm{L})$ and $\mathrm{Cd}(0.25 \mathrm{mg} / \mathrm{L})$ in the Laboratory of Bangladesh Rice Research Institute. Ca and $\mathrm{Mg}$ were extracted by ammonium acetate method (Peech et al. 1947) and determined in FLAAS with the detection limit 0.50 and $0.3 \mathrm{mg} / \mathrm{L}$, respectively. Flame Photometer PFP7 was used for the determination of $\mathrm{Na}$ $(0.20 \mathrm{mg} / \mathrm{L})$.
Total nitrogen content was analyzed by Kjeldahl method (Kjeldahl apparatus, model no. P/N 21284-01, critical value 0.12$)$, percent organic matter $(\mathrm{OM})$ was measured by ashing method (Storer 1984), total organic carbon (TOC) was measured by wet oxidation method as described in Huq and Alam (2005). Soil sulfur was measured turbidimetrically as sulfate (Hunt 1980) (using Tween-80) by UVSpectrophotometer (Model: SPECORD 222A433, Analytik Jena AG, Germany) at $420 \mathrm{~nm}$ wavelength. All the instruments were calibrated before measurement and reagents were of analytical grade (AnalaR). All the glassware, containers and tools were soaked overnight with $20 \%(\mathrm{v} / \mathrm{v})$ nitric acid and finally rinsed with deionized water. All samples were filtered through $0.22 \mu \mathrm{m}$ polycarbonate membrane filter.

\section{Measurement of transfer factor (TF)}

Heavy metal concentrations of soils and crops were calculated on the basis of dry weight. The soil-to-plant transfer factor (TF) of heavy metals $(\mathrm{Fe}, \mathrm{Cu}, \mathrm{Pb}, \mathrm{Zn}, \mathrm{Cd}$ ) from soils to vegetables were calculated using the method of Cui et al. (2004) as follows:

Transfer Factor $(\mathrm{TF})=P / S$

where, $\mathrm{P}$ and $\mathrm{S}$ is the residual concentration of the trace metal in plant tissues and in soil, respectively (ppm dry wt).

\section{Measurement of daily intake of metal (DIM) and health risk index (HRI)}

Health risk index (HRI) was calculated according to the method of Cui et al. (2004). The average daily leafy vegetable intake rate among Bangladeshi people is $0.0361 \mathrm{~kg}$ as found from the survey of Bangladesh Bureau of Statistics (BBS 2011). Data on average adult body weight of Bangladesh was $49.50 \mathrm{~kg}$ (Walpole et al. 2012). Using daily intake of metals (DIM) and reference oral dose $\left(R_{\mathrm{fD}}\right)$, the HRI value was obtained using the following equation.

$\mathrm{HRI}=\mathrm{DIM} / R_{\mathrm{fD}}$

where, $R_{\mathrm{fD}}$ is the reference oral dose $(0.7,0.04,0.3,0.004$, $0.001 \mathrm{mg} / \mathrm{kg} \mathrm{BW} /$ day) for $\mathrm{Fe}, \mathrm{Cu}, \mathrm{Pb}, \mathrm{Zn}$, and $\mathrm{Cd}$, respectively (US-EPA IRIS 2006).

If the value of HRI is less than 1 then the exposed population is said to be safe (Zhuang et al. 2009).

The daily intake of metals (DIM) was calculated to averagely estimate the daily metal loading into the body system of a specified body weight of a consumer. This will inform the relative phyto-availability of metal. This does not take into cognizance the possible metabolic ejection of 
the metals but can easily tell the possible ingestion rate of a particular metal (Cui et al. 2004).

$\mathrm{DIM}=C_{\text {metalconc. }} \times C_{f} \times D_{\text {foodintake }} / \mathrm{BW}$

where, DIM is daily intake of metal $\mathrm{mg} / \mathrm{kg} /$ day; $C_{\text {metal conc. }}$ is heavy metal concentration in plants $(\mathrm{mg} / \mathrm{kg})$, $C_{f}$ is the conversion factor of 0.085 to convert fresh vegetable weight to dry weight, $D_{\text {food intake }}$ is daily intake of leafy vegetables, based on average daily vegetable intake of the country $(\mathrm{g})$ and $\mathrm{BW}=$ average body weight $(\mathrm{kg})$.

\section{Statistical Analysis}

Data were put in Excel. Average of three replications and their standard error was calculated. Preparation of graphs and statistical analysis correlation coefficient and one way ANOVA with post hoc Tukey test was calculated in Origin 9.0 (OriginLab, USA). A 0.05 level of probability was used to calculate the critical value of $F$. If $F$ falls below a fixed threshold, it can be concluded that all the sets of samples have equal averages. Pearson's correlation coefficient with $95 \%$ confidence interval of metal values between soil sample and plant samples were analyzed.

\section{Results and discussion}

\section{Irrigation wastewater characteristics}

The textile industry consumes large quantities of water and produces large volumes of wastewater through various steps in dyeing and finishing processes (Brown and Laboureur 1983). The textile wastewater is a complex and contains variable mixture of polluting substances in terms of high $\mathrm{pH}$, temperature, color, chemical oxygen demand (COD), biochemical oxygen demand (BOD), total suspended solid (TSS), total dissolved solids (TDS), electrical conductivity (EC) and heavy metals. The value of these parameters has been reported to be very high compared to the values in Bangladesh Environmental Conservation Rules (BECR' 1997), set by the government of Bangladesh (Table 3). The sodium hazard or SAR is expressed in terms of classification of irrigation water as low $(\mathrm{S} 1:<10)$, medium (S2: 10-18), high (S3: 18-26) and very high (S4: >26) (Richards 1954). The wastewater of the sampled industry falls into medium SAR hazard. A high SAR value implies a hazard of sodium (Alkali) replacing $\mathrm{Ca}^{2+}$ and $\mathrm{Mg}^{2+}$ in the soil through a cation exchange process that damages soil structure mainly permeability and which ultimately affects the fertility status of the soil and reduce crop field (Gupta 2005).

\section{Morphological changes in plant growth}

Vegetables grown in wastewater-irrigated soil had normal appearance lacking any external visible symptoms. The wet weight versus dry weight of the plant samples indicated that compared to the control, all the treatments had less wet weight as well as dry weight. This indicates although stem and number of leaf is higher, weight (both wet and dry weight) of the plant was being affected by the irrigation scheme to some extent. For plant growth in each treatment, the length of the stem of every individual (Fig. 1a) was measured by a scale, and its number of leaves (Fig. 1b) was counted. It is observed that average length of stem and number of leaf was higher in Treatment 1 compared to the control and other treatments. However, the one way ANOVA did not indicate the presence of any significant variances among the treatments (Table 4). Although approximately $83 \%$ variance exists for T1 in terms of stem length, however, since the $p$ value is 0.186 greater than 0.05 , indicating the null hypothesis is rejected. In terms of wet weight and dry weight, it was observed that compared to control all the treatments had lower wet weight and dry weight (Fig. 1c).

\section{Changes in irrigated soil}

The $\mathrm{pH}$ values of textile wastewater samples were 8.15 and 8.35. On the other hand, soil $\mathrm{pH}$ measured in background soil was $7.12 \pm 0.0352$. With the change of wastewater and fresh water ratio soil $\mathrm{pH}$ was turning to basic. Wastewater irrigation has the potential to add large amounts of salt to the soil (Fig. 2). The increase in electrical conductivity due to sodium content of wastewater may potentially reduce crop yield (Tripler et al. 2011; Rusan et al. 2007). The values of salinity of wastewater samples were 7390 and $7853 \mu \mathrm{S} / \mathrm{cm}$. Percent increase or decrease for soil salinity as measured was positive in all the pots with the range from 46.34 to $246.34 \%$. Moreover, it has been also observed that irrigation with reclaimed wastewater also decreased soil acidity, which is beneficial to the acidic tropical soil (Pereira et al. 2011b). To add here, since Madhupur clay has low CEC (Hoque 1984) and SAR value of wastewater fell into medium SAR hazard, the soil has low SAR hazard.

\%Total $\mathrm{N}$ was found to decrease negatively in all the pots which indicate utilization of nitrogen from the pot soil by the plants and it also indicated no addition of nitrogen from the wastewater. \%Organic Carbon was increased in all the pots which indicated addition of organic carbon in the soil. The most increase was found in pot 2 with the value of $37.50 \%$ changes which had the irrigation ratio of $25 \%$ wastewater with $75 \%$ fresh water. On the other 
Fig. 1 a Average length of stem on the 7th day and 45th day. $\mathbf{b}$ Average number of leaf per plant on the 7th day and 45th day and $\mathbf{c}$ wet weight and dry weight after harvest of the vegetable on 45 th day. The capped bars indicate standard error of three replications
Table 4 Single Factor ANOVA of the plant stem length and number of leaf $(n=1)$

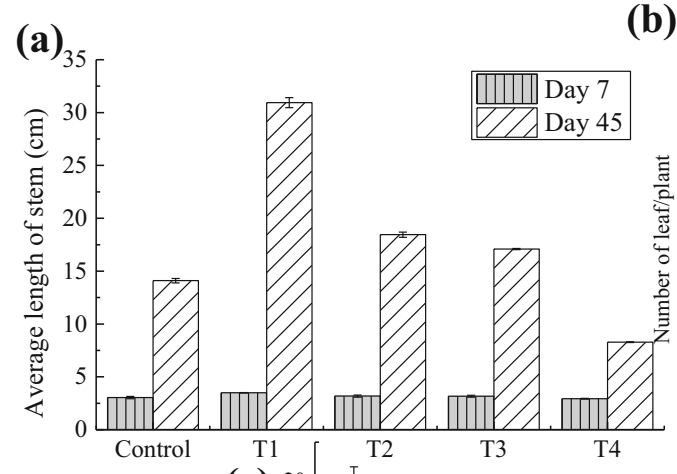

(b)

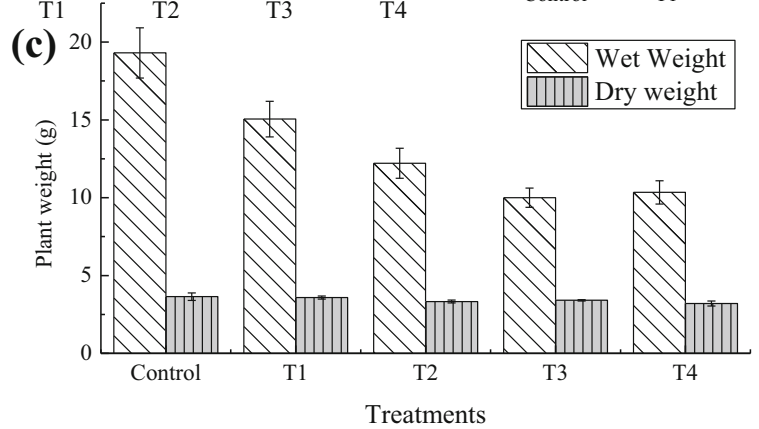

\begin{tabular}{lllllll}
\hline Source of variation & SS & $d f$ & MS & $F$ & $P$ value $(0.05)$ & $F$ crit \\
\hline Between groups & 268.926 & 4 & 67.23149 & 2.354369 & 0.186489 & 5.192168 \\
Within groups & 142.7803 & 5 & 28.55606 & & & \\
Total & 411.7063 & 9 & & & & \\
\hline
\end{tabular}

hand, $\% \mathrm{OM}$ content and $\% \mathrm{~S}$ and $\% \mathrm{P}$ was found to decrease negatively in $100 \%$ wastewater plot, while in other pots, it slightly increased (Fig. 3). The increased alkaline pH, salinity and SAR value of the pot soil due to wastewater irrigation might have an impact on the dissolution of the nutrient. In the plant samples $\% \mathrm{~N}, \% \mathrm{P}$ and $\% \mathrm{~S}$ changed slightly in different treatments compared to the control but the change was not so significant (Fig. 4). Phosphorus $(\mathrm{P})$ is the most important nutrient element (after nitrogen) limiting agricultural production in most regions of the world (Holford 1997; Kogbe and Adediran 2003). The plant available nitrogen and phosphate, and contents of the wastewater-irrigated soil are much lower than the control soil. The lesser nitrogen and potassium content in wastewater- irrigated soil may be also due to wastewater irrigation which reduces the natural microbial activity in the soil, resulting in slower release of plant available nutrients into the soil (Gupta et al. 2010).

It is well known that the biomass uptakes trace metals naturally available to them through soil and stores them in their tissues (Gupta et al. 2010). In the soil sample, the order of metals in terms of highest concentration as recorded were $\mathrm{Fe}>\mathrm{Cu}>\mathrm{Zn}>\mathrm{Pb}>\mathrm{Cd}$ (Fig. 5). While, in the vegetables highest concentrations of metals detected for $\mathrm{Fe}>\mathrm{Zn}>\mathrm{Cu}>\mathrm{Pb}>\mathrm{Cd}$ (Fig. 6). A one way ANOVA analysis along with Tukey test indicated the presence of significant variances among the treatments at 0.05 level in both treated soil $\left(r^{2}=0.9986\right.$ with coefficient of variation 0.082$)$ and plant samples $\left(r^{2}=0.9997\right.$ with coefficient of variation 0.0247 ) for heavy metals.

Correlation coefficient is commonly used to test the relationship between two variables. Individual heavy metal in soil and plant samples was measured for control along with treatments. Pearson's correlation at $95 \%$ level of significance (two tailed test) was calculated for soil-plant heavy metals concentration. Although a high concentration of Fe was reported in plant samples, $\mathrm{Fe}$ in soil treated with wastewater and $\mathrm{Fe}$ in plant samples correlated negatively $\left(r^{2}=-0.36\right)$. The explanation can be given as background soil which is Madhupur clay already contained naturally higher concentration of $\mathrm{Fe}$. Other four heavy metals $\mathrm{Cu}$, $\mathrm{Cd}, \mathrm{Zn}$ and $\mathrm{Pb}$ were positively correlated with $r^{2}$ value $0.55,0.76,0.57$ and 0.46 , respectively. In terms of strength of correlation between soil heavy metal and plant heavy metal the order was $\mathrm{Zn}>\mathrm{Pb}>\mathrm{Cu}>\mathrm{Cd}>\mathrm{Fe}$.

In general, the presence of high concentrations of $\mathrm{Fe}$ and $\mathrm{Zn}$ in the vegetables has been previously reported (Abbasi et al. 2013). However, heavy metals $\mathrm{Cu}, \mathrm{Zn}, \mathrm{Pb}$ and $\mathrm{Cd}$ 

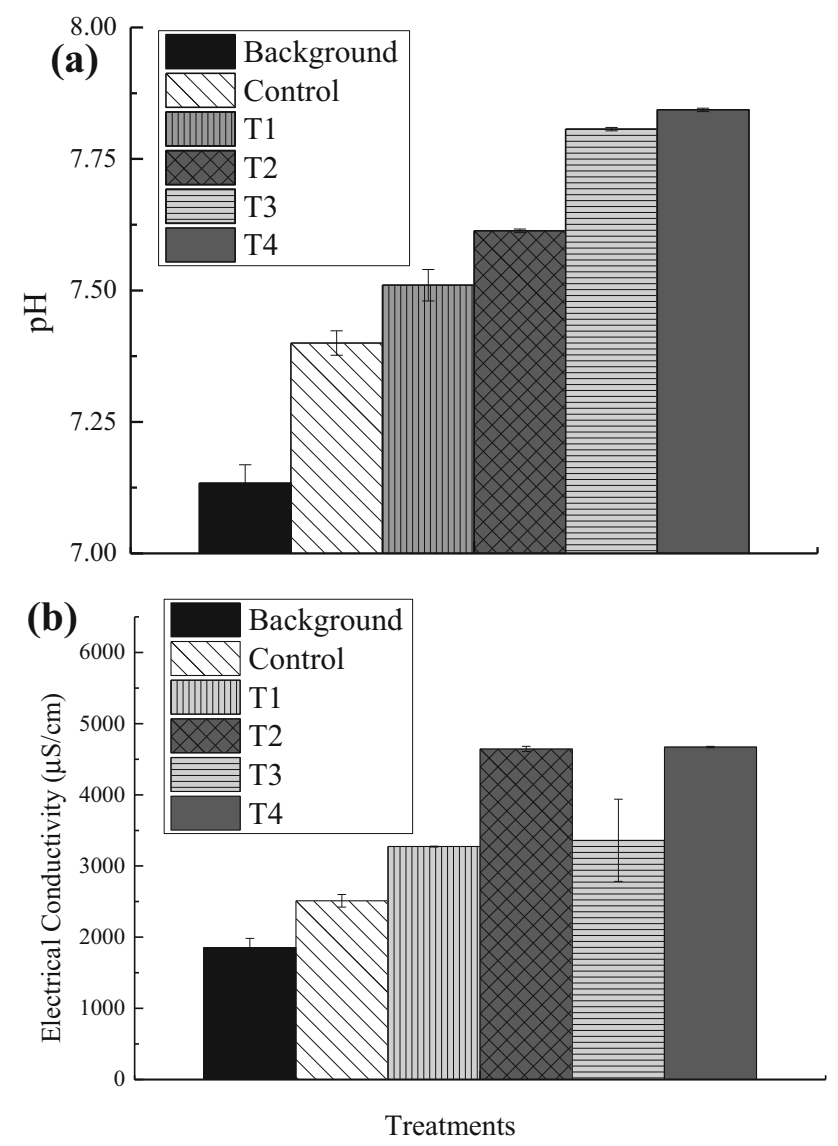

Fig. 2 Changes of soil (a) $\mathrm{pH}$ and (b) electrical conductivity before and after wastewater irrigation. The capped bars indicate standard error of three replications

present in the treatments did not comply within the standard limit of $40 \mathrm{mg} / \mathrm{kg}, 60,5.0$ and $0.2 \mathrm{mg} / \mathrm{kg}$, respectively (FAO/WHO 2011). The accumulation of heavy metals was greater in case of wastewater-irrigated vegetables compared to the control agreeing with previous works (Gupta et al. 2010; Abbasi et al. 2013).

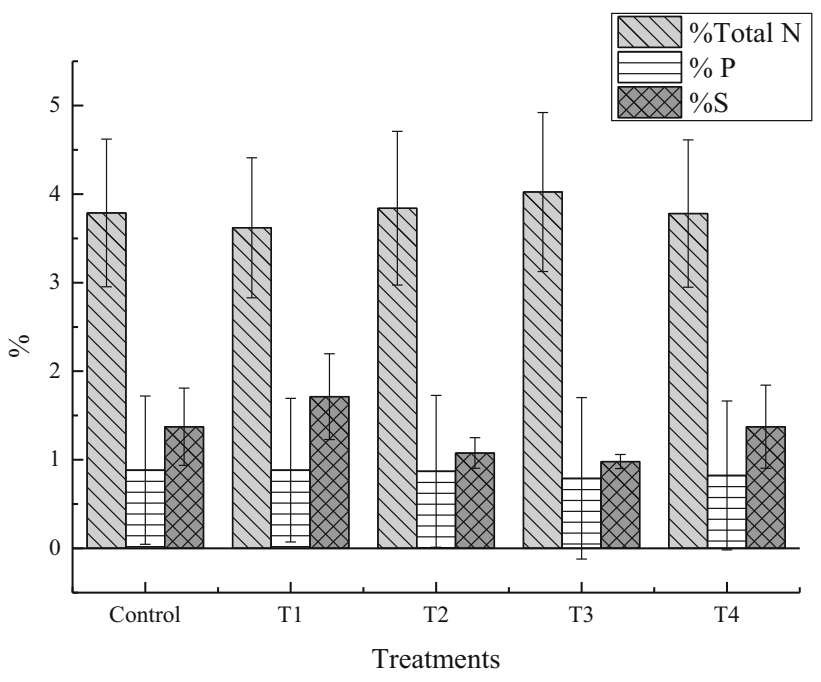

Fig. $4 \%$ Total N, \%P and \%S Sanalyzed in plant samples. The capped bars indicate standard error of three replications

\section{Soil-to-plant transfer factor (TF)}

The TF of heavy metal from soil-to-plant was calculated to determine the relative uptake of heavy metal by the plants with respect to soil irrigated with wastewater. It is important to note here that $\mathrm{TF}$ value of 0.1 indicates that plant is excluding the element from its tissues, the greater the transfer quotient value than 0.50 , the greater will be the chances of vegetables for metal contamination by anthropogenic activities (Khan et al. 2009). A TF value " $>1$ " means higher accumulation of metals in plant parts than in soil (Barman et al. 2000). Soil-to-plant TF is one of the key components of human exposure to metals through food chain (Cui et al. 2004). The higher TF of heavy metal indicates the stronger accumulation of the respective metal by that vegetable (Khan et al. 2009). Therefore, TF of metals is essential to investigate the human HRI (Cui et al.
Fig. 3 Changes of soil \%Total $\mathrm{N}, \%$ Organic carbon, $\%$ Organic matter, $\% \mathrm{~S}$ and $\% \mathrm{P}$. The capped bars indicate standard error of three replications

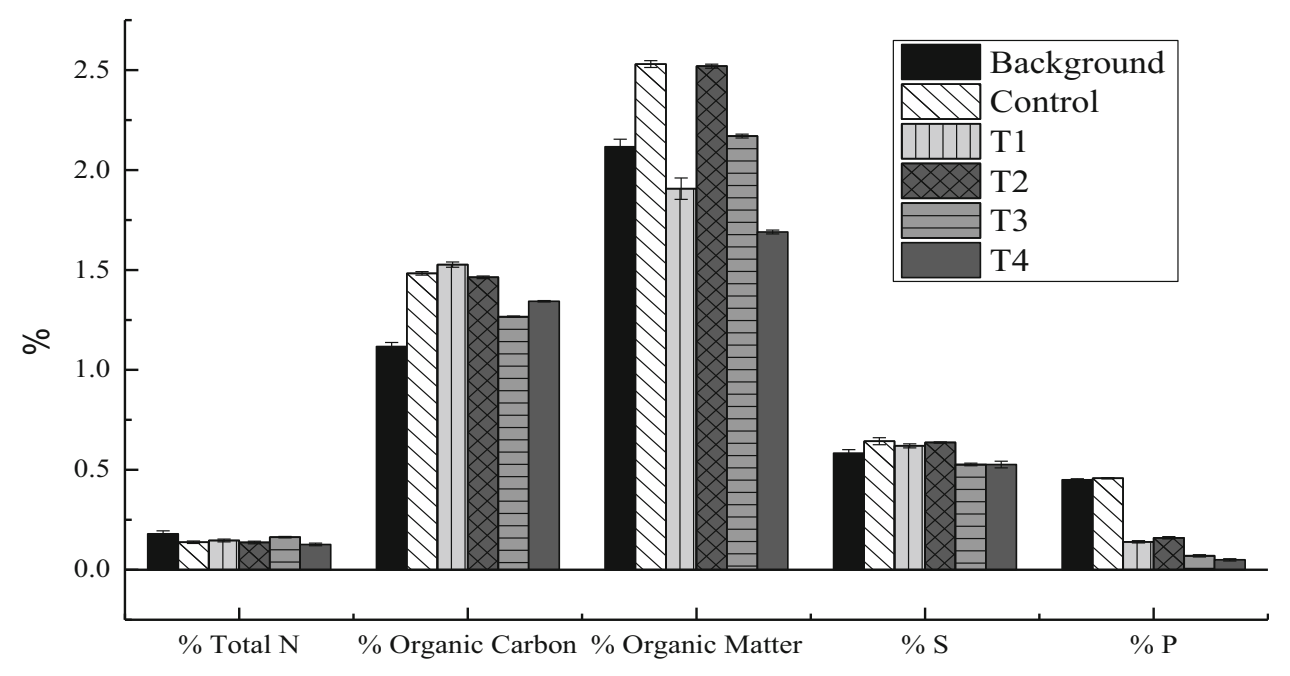




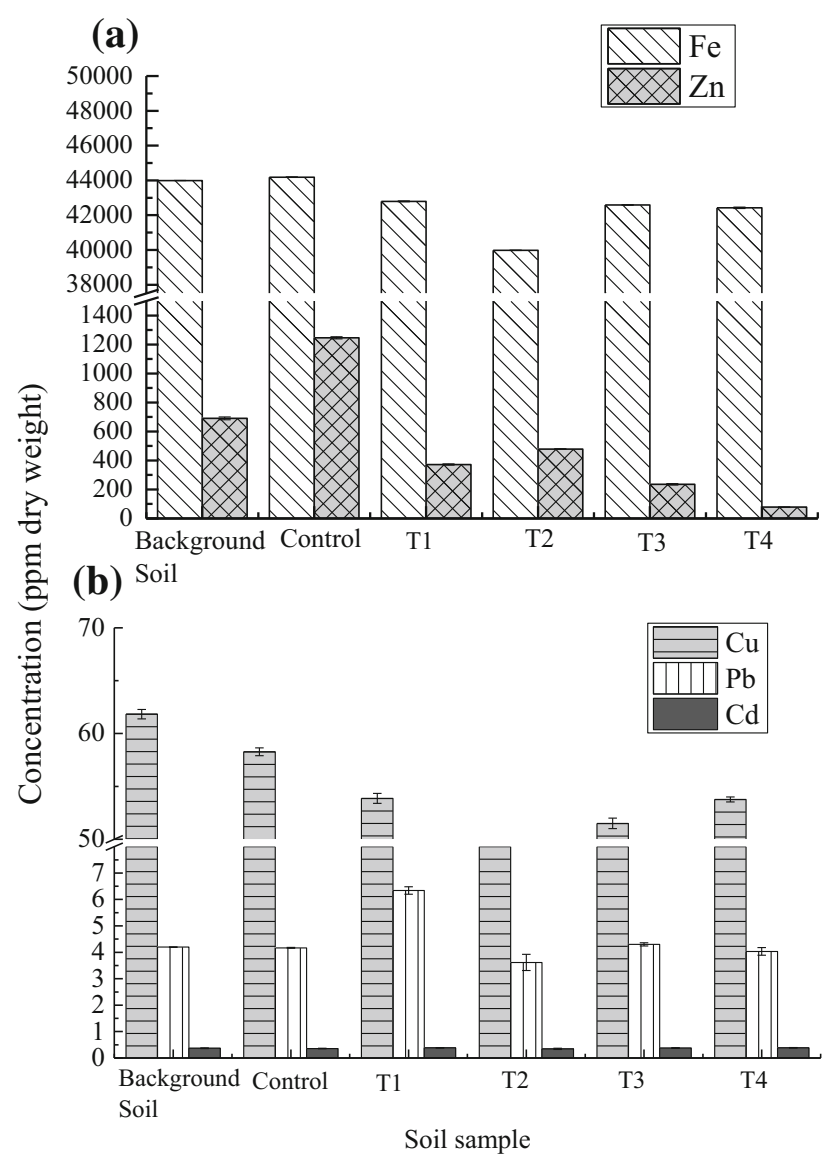

Fig. 5 Concentration of different metal contents in soil sample of different treatments. a $\mathrm{Fe}$ and $\mathrm{Zn}$ concentrations (b) $\mathrm{Cu}, \mathrm{Cd}$ and $\mathrm{Pb}$ concentrations. The capped bars indicate standard error of three replications

2004). Higher values of TF suggest poor retention of metals in soil and/or more translocation in plants. Leafy vegetables accumulate much higher contents of heavy metals than other vegetables because their higher translocation and transpiration rates (Zhuang et al. 2009; Khan et al. 2009).

Except for $\mathrm{Fe}$, heavy metals $\mathrm{Pb}, \mathrm{Cu}, \mathrm{Cd}$ and $\mathrm{Zn}$ showed a higher TF, which is also in agreement with correlation coefficient analysis of concentration of metal in soil and concentration of metal in plants. Soil-to-plant TF in the control irrigation treatment was in the order $\mathrm{Pb}>\mathrm{Cu}>\mathrm{Cd}>\mathrm{Zn}>\mathrm{Fe}$. Except $\mathrm{T} 1$ and $\mathrm{T} 4, \mathrm{~T} 2$ and $\mathrm{T} 3$ maintained a similar pattern of TF of the metals as to the control pots (Fig. 7). Soil-to-plant TF in T1 and T4 were $\mathrm{Cu}>\mathrm{Pb}>\mathrm{Cd}>\mathrm{Zn}>\mathrm{Fe}$ and $\mathrm{Pb}>\mathrm{Cu}>\mathrm{Zn}>\mathrm{Cd}>\mathrm{Fe}$. According to data in Fig. 7, $\mathrm{Cu}$ and $\mathrm{Pb}$ showed mean $\mathrm{TF}$ values in the range from 1 to 1.7 indicating their accumulation in $B$. alba plants and then the potential health risk of these two metals by dietary exposure. Metals transfer from soil in plant depends on plant bioavailability and

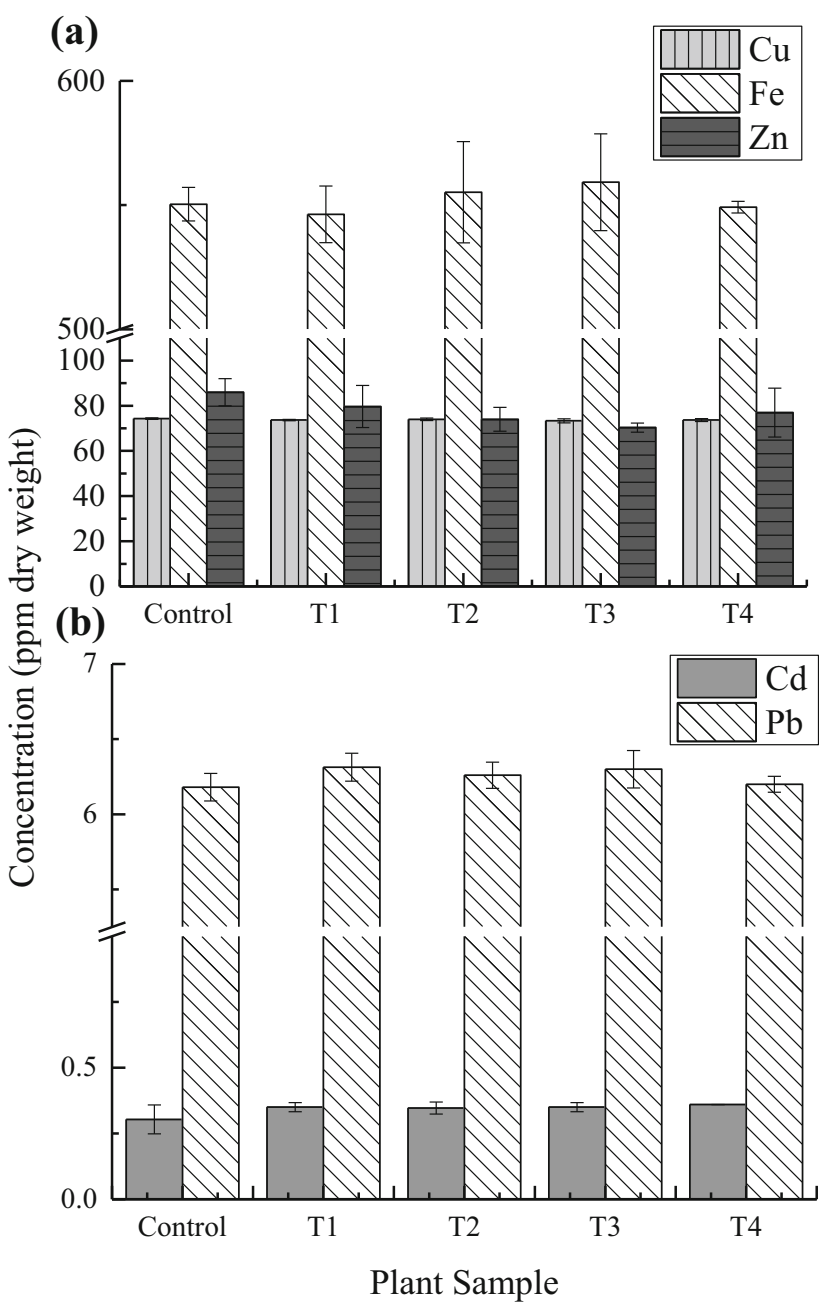

Fig. 6 Selected metal contents analyzed in plant samples (a) $\mathrm{Cu}, \mathrm{Fe}$ and $\mathrm{Zn}$ concentrations (b) $\mathrm{Cd}$ and $\mathrm{Pb}$ concentrations. The capped bars indicate standard error of three replications

independent of metal and plant type (Intawongse and Dean 2006). However, a complex positive (synergistic) or negative (antagonist) interactions may occur between them, thus increasing or decreasing their availability depending on the type and amount of other metals present in the soil and the soil characteristics, mainly salinity and pH. Figure 7 also indicated where some interactions could be potentially interpreted, for example positive relationship between $\mathrm{Cu}$ and $\mathrm{Zn}$, vs. $\mathrm{Pb}$ (which decreased) as in $\mathrm{T} 1$, or negative between $\mathrm{Zn}$ and $\mathrm{Pb}, \mathrm{Cu}$ and $\mathrm{Cd}$ from $\mathrm{T} 2$ to $\mathrm{T} 4$ when salinity and metal concentration increased. However, to understand this relationship needs more exploration.

\section{Health risk index (HRI)}

There are various possible exposure pathways of pollutants to humans. Principally, the food chain (soil-plant-human) pathway is recognized as one of major pathways for human 
Fig. 7 Soil-to-plant Transfer Factor (TF) of Basella alba treated with different treatments in compared to the control. The capped bars indicate standard error of three replications

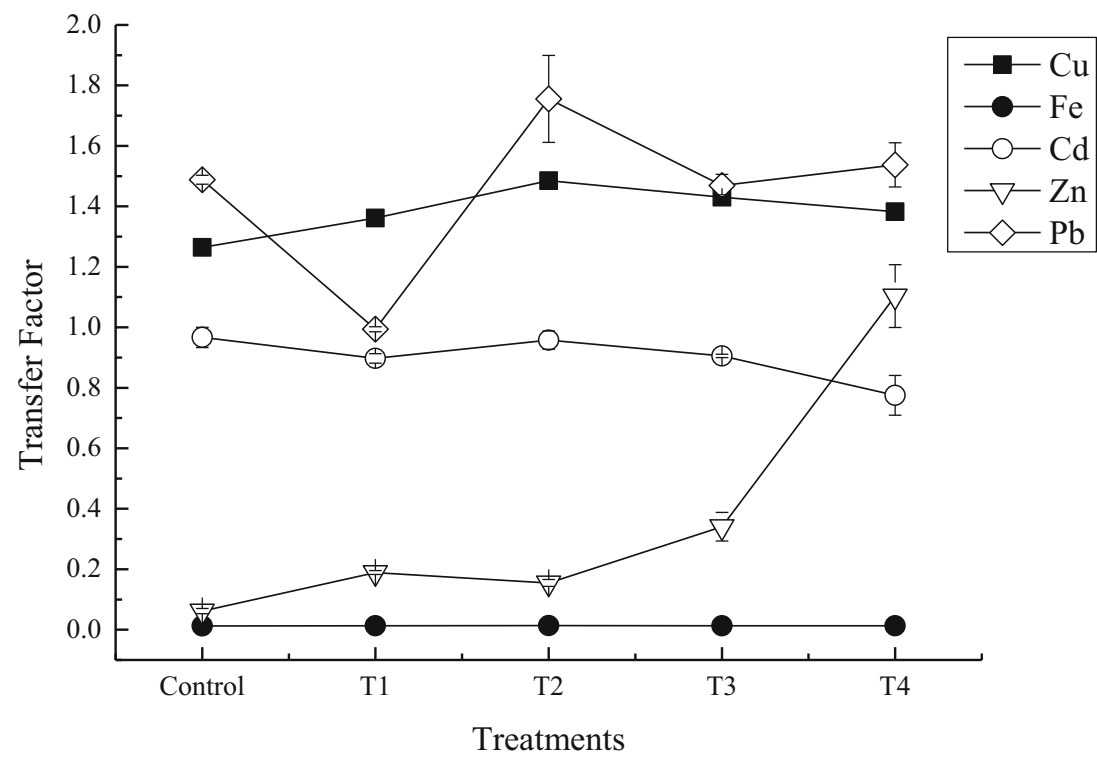

Table 5 Calculation of Health Risk Index (HRI) of Basella alba

\begin{tabular}{lllllll}
\hline & $\mathrm{Cu}$ & $\mathrm{Fe}$ & $\mathrm{Zn}$ & $\mathrm{Pb}$ & $\mathrm{Cd}$ & Cumulative HRI \\
\hline Control & 0.11 & 0.05 & 0.02 & 0.10 & 0.02 & 0.30 \\
$\mathrm{~T} 1$ & 0.11 & 0.05 & 0.02 & 0.10 & 0.02 & 0.30 \\
$\mathrm{~T} 2$ & 0.11 & 0.05 & 0.02 & 0.10 & 0.02 & 0.30 \\
$\mathrm{~T} 3$ & 0.11 & 0.05 & 0.01 & 0.10 & 0.02 & 0.30 \\
$\mathrm{~T} 4$ & 0.12 & 0.05 & 0.02 & 0.10 & 0.02 & 0.31 \\
\hline
\end{tabular}

exposure to soil contamination (Zhuang et al. 2009; Khan et al. 2008). Vegetables are an essential part of diet and are taken both cooked and raw forms by human (Jolly et al. 2013). Leafy vegetables in Bangladesh are normally eaten as cooked form. Although some metals present in vegetables are biochemically essential for humans, concentrations higher than those recommended may cause metabolic disorders (Jolly et al. 2013). The health protection standard of HRI is 1.0 (USEPA 2006). HRI higher than 1 indicates high level of metal exposure from these leafy vegetables. If HRI is lower than 1, the exposed population is said to be safe.

By comparing the estimated dietary intake and target health risk index for $\mathrm{Cu}, \mathrm{Fe}, \mathrm{Zn}, \mathrm{Pb}$ and $\mathrm{Cd}$, this study determined that there was no potential health risk for the local inhabitants through consumption of contaminated vegetables. In this study, HRI values of the metals as shown in Table 5 in control and treatments were less than unity. Moreover, the cumulative HRI values for the heavy metals for each treatment were also found to be less than unity. Consequently, the consumption of the vegetables was considered to be safe. Though the background soil collected from the agricultural land near textile industry as well as the wastewater for irrigation with different combination of groundwater do not possess health risk from consumption of these vegetables. However, over many years may be associated with non-carcinogenic health risks (Table 5). As for $0.33 \mathrm{HRI}$ obtained for one harvest and the level of salinity long term consumption of these vegetables may link to a chronic health risk. Although HRI-based risk assessment method does not deliver a quantitative estimation for the likelihood of an exposed population undergoing a reverse health effect, it indeed provides a suggestion of health risk level due to exposure to pollutants (Chary et al. 2008).

\section{Conclusion}

The impacts of textile wastewaters on agricultural land and production are now burning issues for the sustainable industrial development of countries like Bangladesh. Application of wastewater as irrigation water for agriculture in urban and peri-urban areas sustainably reuses water resources but threaten the soil quality to be deteriorated, with less microbial activities, high salinity and heavy metals accumulation over time. It also causes vegetable contamination by transfer from soil-to-plant tissues which presume a great chronic health risk to the consumers of these vegetables on regular basis by dietary exposure particularly linked to poor food quality and metal accumulation. Therefore, the consumption of vegetables from the agricultural fields contaminated with continuous exposure of textile wastewater for irrigation should be avoided and consumption of these vegetables on regular basis is not recommended. 
Acknowledgments This project was supported by Jahangirnagar University Science Research Grant no. FY (2009-10)/2903(170) and provided to Ms. Mashura Shammi. Authors would also like to thank anonymous reviewers for their remarkable suggestions in improving the manuscript.

Author contribution All authors read and approved the final manuscript.

\section{Compliance with ethical standards}

Conflict of interest The authors declare that they have no competing interests.

Open Access This article is distributed under the terms of the Creative Commons Attribution 4.0 International License (http://crea tivecommons.org/licenses/by/4.0/), which permits unrestricted use, distribution, and reproduction in any medium, provided you give appropriate credit to the original author(s) and the source, provide a link to the Creative Commons license, and indicate if changes were made.

\section{References}

Abbasi AM, Iqbal J, Khan MA, Shah MH (2013) Health risk assessment and multivariate apportionment of trace metals in wild leafy vegetables from lesser Himalayas, Pakistan. Ecotoxicol Environ Saf 92:237-244. doi:10.1016/j.ecoenv.2013.02.011

Ahmed G, Sultana M, Chowdhury DA, Khan G, Ahmad JU (2007) Characterization of Dhaka export processing zone (DEPZ) wastewater by study of some physicochemical properties. J Bangladesh Environ Sci 5:105-115

Alam MGM, Snow ET, Tanaka A (2003) Arsenic and heavy metal contamination of vegetables grown in Samta village, Bangladesh. Sci Total Environ 308(1-3):83-96. doi:10.1016/s00489697(02)00651-4

Al-Rmalli SW, Jenkins RO, Haris PI (2012) Dietary intake of cadmium from Bangladeshi foods. J Food Sci 77(1):T26-T33. doi:10.1111/j.1750-3841.2011.02467.x

An TD, Tsujimura M, Le Phu V, Kawachi A, Ha DT (2014) Chemical characteristics of surface water and groundwater in coastal watershed, Mekong Delta, Vietnam. Proc Environ Sci 20:712-721

APHA (1998) Standard methods for the examination of water and wastewater. American Public Health Association, Port City Press, Maryland

Barman SC, Sahu RK, Bhargava SK, Chatterjee C (2000) Distribution of heavy metals in wheat, mustard and weed grown in fields irrigated with industrial effluents. Bull Environ Contam Toxicol 64:489-496

BBS (2011) Report of the household income and expenditure survey 2010. Bangladesh Bureau of Statistics. http://www.bbs.gov.bd/ webtestapplication/userfiles/image/HIES-10/Chapter-05.pdf. Accessed 1 Sept 2012

Brown D, Laboureur P (1983) The aerobic biodegradability of primary aromatic amines. Chemosphere 12:405-414

Chary NS, Kamala CT, Raj DSS (2008) Assessing risk of heavy metals from consuming food grown on sewage irrigated soils and food chain transfer. Ecotoxicol Environ Saf 69:513-524

Cui YJ, Zhu YG, Zhai RH, Chen DY, Huang YZ, Qiu Y, Liang JZ (2004) Transfer of metals from soil to vegetables in an area near a smelter in Nanning, China. Environ Int 30(6):785-791. doi:10. 1016/j.envint.2004.01.003

El-Rahim WM, Khalil WK, Eshak MG (2008) Genotoxicity studies on the removal of a direct textile dye by a fungal strain, in vivo, using micronucleus and RAPD-PCR techniques on male rats. J Appl Toxicol 28(4):484-490. doi:10.1002/jat.1299

FAO/WHO (2011) Joint FAO/WHO food standards programme codex committee on contaminants in foods, fifth session. http:// faolex.fao.org/docs/pdf/bgd19918.pdf. Accessed 1 Sept 2012

Ganoulis J (2012) Risk analysis of wastewater reuse in agriculture. Int J Recycl Org Waste Agric 1:3-9. doi:10.1186/2251-7715-1-3

Gupta PK (2005) Methods in environmental analysis: water, soil and air. Agrobios, Jodhpur

Gupta S, Satpati S, Nayek S, Garai D (2010) Effect of wastewater irrigation on vegetables in relation to bioaccumulation of heavy metals and biochemical changes. Environ Monit Assess 165:169-177

Haque ME, Nairuzzaman M, Sayem HM, Imam H (2013) Evaluation and variation of shrinkage parameters of the Madhupur clay samples of Savar and Dhaka and their relation with clay minerals. Bangladesh Geosci J 19:1-14

Holford ICR (1997) Soil phosphorus: its measurement, and its uptake by plants. Aust J Soil Res 35:227-239

Hoque MZ (1984) Cropping systems in Asia. On-farm research and management. International Rice Research Institute, Los Baños

Hu X, Ding Z (2009) Lead/Caadmium contamination and lead isotopic ratios in vegetables grown in peri-urban and mining/ smelting contaminated sites in Nanjing, China. Bull Environ Contam Toxicol 82(1):80-84. doi:10.1007/s00128-008-9562-y

Hu J, Wu F, Wu S, Cao Z, Lin X, Wong MH (2013) Bioaccessibility, dietary exposure and human risk assessment of heavy metals from market vegetables in Hong Kong revealed with an in vitro gastrointestinal model. Chemosphere 91(4):455-461. doi:10. 1016/j.chemosphere.2012.11.066

Hunt J (1980) Determination of total sulfur in small amount of plant material. Analyst 105:83-85

Huq SMI, Alam MD (2005) A handbook on analyses of soil, plant, and water. BACER-DU, University of Dhaka, Bangladesh

Huq SMI, Uddin J, Shoaib M (2013) The soils of Bangladesh. Springer, Berlin

Intawongse M, Dean JR (2006) Uptake of heavy metals by vegetable plants grown on contaminated soil and their bioavailability in the human gastrointestinal tract. Food Addit Contam 23(1):36-48. doi:10.1080/02652030500387554

Jolly YN, Islam A, Akbar S (2013) Transfer of metals from soil to vegetables and possible health risk assessment. Springer Plus 2(385):1-8. doi:10.1186/2193-1801-2-385

Kabir S, Kabir M, Alam S, Mia C, Chowdhury D, Sultana M, Rahman S (2002) Assessment of wastewater quality of Dhaka export processing zone with special emphasis to that of the textile and dyeing industries. Jahangirnagar Univ J Sci 25:137-145

Khan S, Cao Q, Zheng YM, Huang YZ, Zhu YG (2008) Health risks of heavy metals in contaminated soils and food crops irrigated with wastewater in Beijing, China. Environ Pollut 152(3):686-692. doi:10.1016/j.envpol.2007.06.056

Khan S, Farooq R, Shahbaz S, Khan MA, Sadique M (2009) Health risk assessment of heavy metals for population via consumption of vegetables. World App Sci J 6(12):1602-1606

Khan MKA, Alam M, Islam MS, Hassan MQ, Al-Mansur M (2011) Environmental pollution around Dhaka EPZ and its impact on surface and groundwater. Bangladesh $\mathbf{J}$ Sci Ind Res 46(2):153-162

Klay S, Charef A, Ayed L, Houman B, Rezgui F (2010) Effect of irrigation with treated wastewater on geochemical properties (saltiness, C, N and heavy metals) of isohumic soils (Zaouit Sousse perimeter, Oriental Tunisia). Desalination 253(1-3):180-187. doi:10.1016/j.desal.2009.10.019

Kogbe JOS, Adediran JA (2003) Influence of nitrogen, phosphorus and potassium application on the yield of maize in the savanna zone of Nigeria. Afr J Biotech 2(10):345-349 
Mahfuz M, Ahmad J, Sultana M, Rahman M, Goni M, Rahman M (2004) Status of physico-chemical properties of wastewater in Bangladesh: a case studies in Dhalai Beel of DEPZ. J Bangladesh Environ Res 2:9-15

Mahmood A, Malik RN (2014) Human health risk assessment of heavy metals via consumption of contaminated vegetables collected from different irrigation sources in Lahore, Pakistan. Arab J Chem 7(1):91-99. doi:10.1016/j.arabjc.2013.07.002

MOEF (Ministry of Environment and Forest)/DOE (Department of Environment)/GOB (Government of Bangladesh) (1997) The Environment Conservation Rules, (BECR') http://www.moef. gov.bd/html/laws/env_law/178-189.pdf. Acessed 1 Sept 2012

Muyen Z, Moore GA, Wrigley RJ (2011) Soil salinity and sodicity effects of wastewater irrigation in South East Australia. Agric Water Manage 99(1):33-41. doi:10.1016/j.agwat.2011.07.021

Nabulo G, Young SD, Black CR (2010) Assessing risk to human health from tropical leafy vegetables grown on contaminated urban soils. Sci Total Environ 408(22):5338-5351. doi:10.1016/ j.scitotenv.2010.06.034

Peech ML, Alexander T, Dean LA, Reed JF (1947) Methods of soil analysis for soil fertility investigations. USDA Circ 757:25

Pereira BFF, He ZL, Stoffella PJ, Melfi AJ (2011a) Reclaimed wastewater: effects on citrus nutrition. Agric Water Manage 98(12):1828-1833. doi:10.1016/j.agwat.2011.06.009

Pereira BF, He ZL, Silva MS, Herpin U, Nogueira SF, Montes CR, Melfi AJ (2011b) Reclaimed wastewater: impact on soil-plant system under tropical conditions. J Hazard Mater 192(1):54-61. doi:10.1016/j.jhazmat.2011.04.095

Qadir M, Wichelns D, Raschid-Sally L, McCornick PG, Drechsel P, Bahri A, Minhas PS (2010) The challenges of wastewater irrigation in developing countries. Agric Water Manage 97(4):561-568. doi:10.1016/j.agwat.2008.11.004

Ranganathan K, Karunagaran K, Sharma DC (2007) Recycling of wastewaters of textile dyeing industries using advanced treatment technology and cost analysis-case studies. Resour Conserv Recycl 50(3):306-318. doi:10.1016/j.resconrec.2006.06.004

Richards LA (1954) Diagnosis and improvement of saline and alkali soils. US Department of Agricultural Hand-book, Washington DC
Rusan MJM, Hinnawi S, Rousan L (2007) Long term effect of wastewater irrigation of forage crops on soil and plant quality parameters. Desalination 215(1-3):143-152. doi:10.1016/j.desal. 2006.10 .032

Salakinkop SR, Hunshal CS (2014) Domestic sewage irrigation on dynamics of nutrients and heavy metals in soil and wheat (Triticum aestivum L.) production. Int J Recycl Org Waste Agric 3:64. doi:10.1007/s40093-014-0064-0

Shammi M, Hossain D, Kashem MA, Rahman MM, Uddin MK (2014) Assessment of irrigation water reuses potentiality of Dhaka export processing zone (DEPZ) wastewater and its impact on soil toxicity. Int J Env Sci 4(5):719-729. doi:10.6088/ijes. 2014040404512

Storer DA (1984) A simple high sample volume ashing procedure for determining soil organic matter. Commun Soil Sci Plant Anal 15:759-772

Toze S (2006) Reuse of wastewater water-benefits and risks. Agric Water Manage 80(1-3):147-159. doi:10.1016/j.agwat.2005.07. 010

Tripler E, Shani U, Mualem Y, Ben-Gal A (2011) Long-term growth, water consumption and yield of date palm as a function of salinity. Agric Water Manage 99(1):128-134. doi:10.1016/j. agwat.2011.06.010

US-EPA IRIS (2006) United States, Environmental Protection Agency, Integrated Risk Information System. http://www.epa. gov/iris/substS. Accessed 1 Sept 2012

Walpole SC, Prieto-Merino D, Edwards P, Cleland J, Stevens G, Roberts I (2012) The weight of nations: an estimation of adult human biomass. BMC Public Health 12:439. doi:10.1186/14712458-12-439

Zhuang P, McBride MB, Xia H, Li N, Li Z (2009) Health risk from heavy metals via consumption of food crops in the vicinity of Dabaoshan mine, South China. Sci Total Environ 407(5):1551-1561. doi:10.1016/j.scitotenv.2008.10.061 